\title{
Assessment of Possibilities of Electricity Production in Flash Geothermal System in Poland
}

\begin{abstract}
An analytical method is described that expresses the specific power of a flash geothermal power plant with flash temperature regarded as a variable. The analysis was carried out for a condensation temperature for fluid exiting a theoretical turbine and for a given geothermal reservoir temperature. The method is a linear approximation of the established method for optimizing separator pressure. This linear approximation makes it possible to obtain an analytical expression for the optimum flash temperature (fixing the separation pressure) at which the maximal specific power is obtained.

A discussion arose in Poland during extensive research related to the application of binary systems, HDR (Hot Dry Rock), and EGS (Enhanced Geothermal System) technologies for the production of electricity. This concerned the hypothetical possibility of using geothermal flash systems for this purpose. Therefore, the above procedure was applied to Polish geothermal conditions to assess the theoretical possibilities of operating such systems at the reservoir temperatures anticipated in Poland. In the lower Triassic formations in central Poland, there are geothermal resources with temperatures hovering above $130^{\circ} \mathrm{C}$. However, low net power values were estimated following the application of the procedure; when combined with the large investment costs involved (the high-temperature resources lie at a depth more than $4000 \mathrm{~m}$ ), this is not condusive for the efficient application of such systems. On the other hand, the possible application of binary systems to electricity production in that area is realistic and justified.
\end{abstract}

Keywords: geothermal energy, geothermal power plant, flash cycle, specific power, Poland

* AGH University of Science and Technology, Faculty of Mining Surveying and Environmental Engineering, Department of Environmental Management and Protection, Krakow, Poland 


\section{Introduction}

The variety of reservoir conditions in Poland demonstrates the variety of possible contexts in which geothermal energy can be used (adjusted to local conditions and needs).

Growing interest has been observed here, especially in the geothermal bathing sector (which has attracted private investors). Systems based on deep hydrothermal resources as well as on shallow groundwater and rock formations (heat pumps) have successfully been exploited [2, 3, 5, 16, 19].

It is also worth noticing that the interest in recreation and balneotherapy is growing. Eight new centers have been opened in Poland in recent years [12]. In some cases, geothermal waters have been proposed not only as an exclusive energy source but also as a source of fresh water after desalination [17, 18].

However, compared to the well-known Italian (Larderello), Icelandic (Nesjavellir), Turkish (Germencik), New Zealand (Wairakei), American (Geysers), and Japanese (Otake) geothermal resources, Polish geothermal resources look much more modest in terms of energy. Of course, Poland is not on a tectonic plate boundary, and only the central part of Poland has conditions for the production of electricity. These geothermal resources can be classified as intermediate resources $[2,4]$.

Recently, large-scale research has been carried out in Poland on the possibilities for using geothermal energy in the production of electricity in HDR (Hot Dry Rock) and EGS (Enhanced Geothermal System) systems. Future deep drilling is planned in Poland, and HDR technology gives us the opportunity to find geothermal resources at depths of $4000-5000 \mathrm{~m}$, with temperatures significantly exceeding $100^{\circ} \mathrm{C}$. Such opportunities occur in central Poland in the lower Triassic formations [10] as well as the granite structures of the Karkonosze mountains (region of Sudetes) [7].

The potential possibility of finding reservoirs with temperatures above $130^{\circ} \mathrm{C}$ in these structures prompted speculation about the theoretical possibility of applying single flash systems for the production of electricity. The use of geothermal resources with such temperatures in flash systems has been discussed in numerous papers (e.g., $[9,15])$.

In Poland, however, there is no reliable borehole data relating to the thermodynamic parameters in such zones nor giving well productivity curves providing information on the relationship between the mass flow rate and wellhead pressure. Because these parameters were arbitrarily established, the estimates presented in this paper are more of an indication and guide than hard data for practical use for a specific project.

The analyses were intended to estimate the optimal parameters required for a hypothetical flashing process to achieve the maximum power for a geothermal power plant. The problem of maximizing the power output of a single flash plant is a well-known issue and involves identifying the optimal flash temperature at which the maximum of the product of the steam mass flow rate and expansion enthalpy are 
obtained (for any given wellhead and condensation temperatures). An important element of the analysis is the fact that, with reducing flash temperatures, the steam mass flow rate increases; however, the expansion enthalpy decreases. The standard estimation of the optimal value of flash temperature applies the formula of defining the square root of the product of the absolute wellhead and absolute condensation temperatures. The article presents an alternative formula and compares the obtained results based on the procedure presented, the square root formula, and thermodynamic diagrams.

\section{Power Estimation of Flash Cycle in Geothermal Plant}

A schematic diagram for a simple flash geothermal plant is presented in Figure 1. Flash steam plants are used to generate power from liquid-dominated resources that are hot enough to flash the water to steam in surface equipment (e.g., via a flash valve).

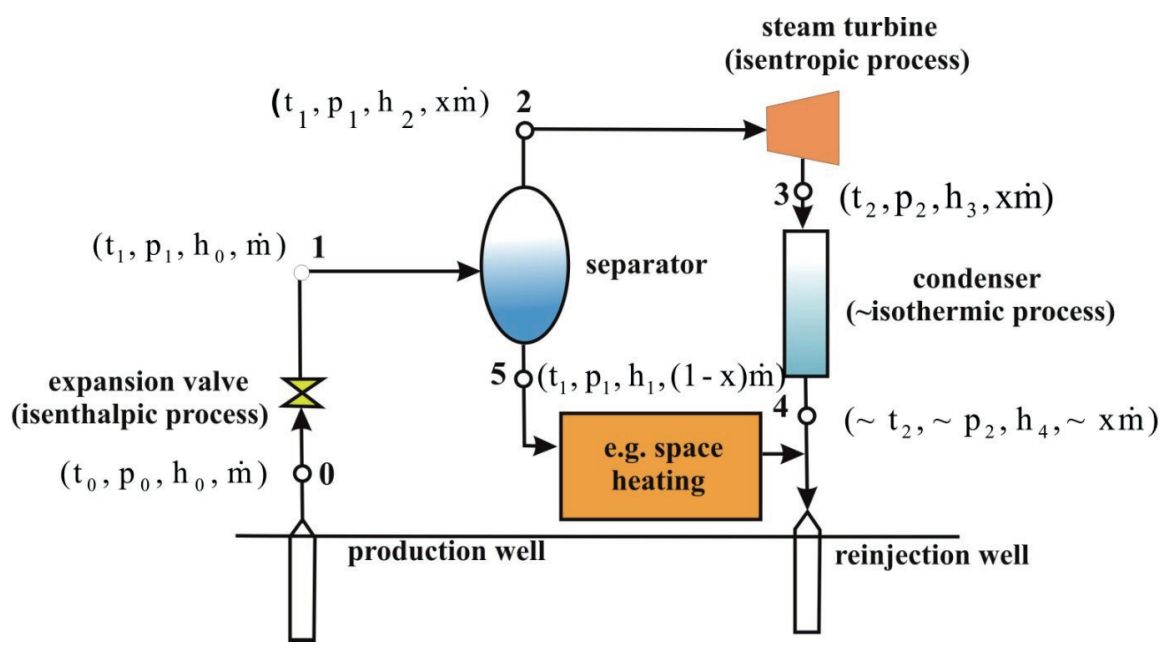

Fig. 1. Scheme of single flash geothermal power plant (characteristic points and symbols as in Figure 2): $t$ - temperature, $p$ - pressure, $h$-specific enthalpy, - mass flow rate, $x$-dryness (steam) fraction

The steam flows through the turbine to produce power, while the brine can serve as the input heat for space heating and/or a binary cycle plant before being re-injected back into the well. Steam exiting the turbine is condensed in the condenser and also re-injected into the same well. A method for expressing the efficiency and specific power of a flash geothermal plant as a function of flash temperature was examined by Ryley [14]. 
Issues referring to geothermal flash plants were presented in papers by DiPippo [8] and Kanoglu, Dincer and Rosen [11], among others.

In the analysis presented, the following are assumed: saturated thermal water (mostly two-phase fluids) at the wellhead $\left(t_{0^{\prime}} p_{0}\right)$, an isenthalpic flash process, a minimum flash temperature $\left(t_{1}\right)$ of $100^{\circ} \mathrm{C}$ (with a minimum flash pressure $p_{1}$ of $1 \mathrm{bar}$ ), and a maximum thermal water temperature $t_{0}$ up to $250^{\circ} \mathrm{C}$ ( $p_{0}$ up to $40 \mathrm{bar}$ ).

In a conventional steam turbine, the geothermal power $(W)$ is the change in the isentropic enthalpy that takes the turbine efficiency and mass flow rate into account:

$$
W=\eta \dot{m}\left(h_{2}-h_{3}\right)
$$

where:

$h_{2}$ - specific enthalpy of steam entering the turbine,

$h_{3}$ - specific enthalpy of fluid exiting the turbine (assuming an isentropic turbine),

$\eta$ - turbine efficiency (usually $0.75-0.85$ ),

$\dot{m}$ - total mass flow rate from the well (also depending on the flash temperature in most cases).

In a flash system, the mass flow rate entering the turbine (Fig. 1) equals $x \cdot \dot{m}$; thus, according to (1), the specific power of the turbine is:

$$
W=\eta x\left(h_{2}-h_{3}\right)
$$

where:

$h_{2}$ - specific enthalpy of saturated steam (Point 2, Fig. 2) at flash temperature $t_{1}$

$h_{3}$ - specific enthalpy of fluid exiting the turbine at condensation temperature $t_{2}$ (Point 3, Fig. 2)

$x$ - steam fraction (Point 1 , Fig. 2a).

It is a known fact that, if $x$ increases during the flash process, the difference of enthalpy drops $\left(h_{2}-h_{3}\right)$; thus, getting more steam does not always mean increasing the power value. The change in $\mathrm{x}$ is produced by the isenthalpic decrease of flash temperature and pressure (Figs. 1, 2). This relationship is seen in Diagram $(t-h)$ (Fig. 2b) and can be written as:

$$
x=\Delta h / R_{1}=\Delta h /\left(R_{0}+\Delta h-\delta h\right)
$$

where:

$R_{1}$ - latent heat for flash temperature $t_{1}$ and pressure $p_{1^{\prime}}$

$R_{0}$ - latent heat for thermal water temperature $t_{0}$ and pressure $p_{0}$. 
a)

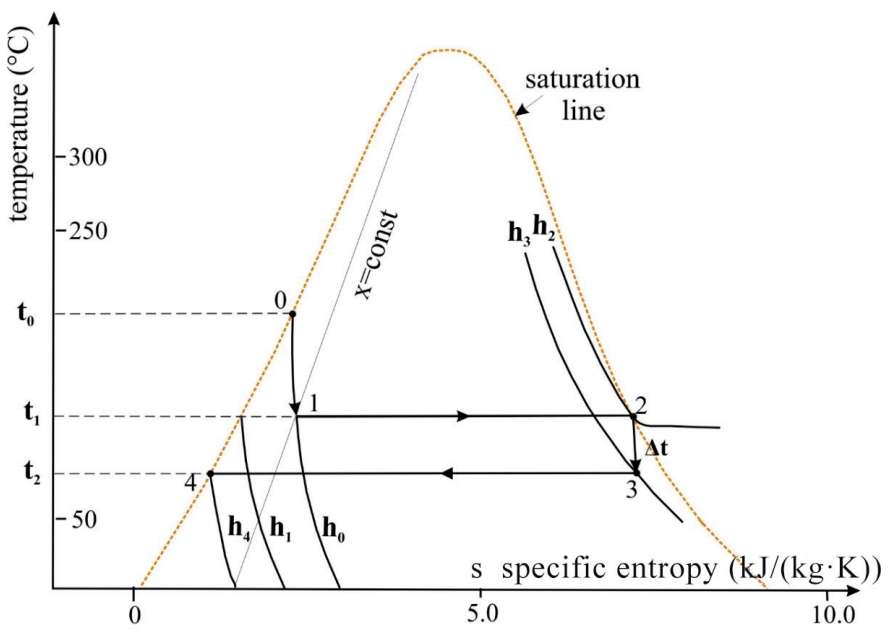

b)

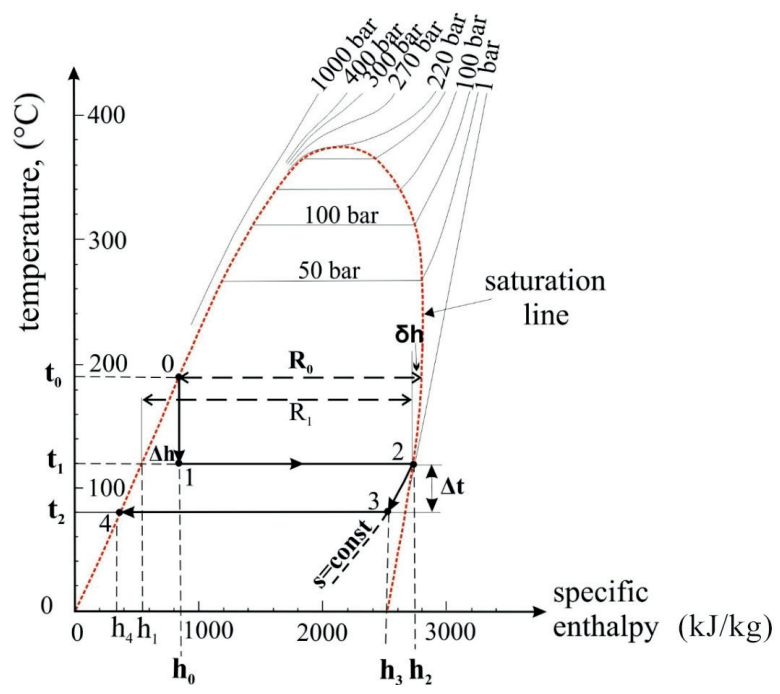

Fig. 2. Flash cycle on temperature - entropy diagram $(t-s)(a)$; flash cycle on temperature - enthalpy diagram $(t-h)(b)$

It was assumed that, in the range of changes $t_{1}=\left(100-250^{\circ} \mathrm{C}\right)$, the value of factor $\delta h$ is negligible (small changes of $h_{2}$ ); thus, equation (3) can be written in the following form:

$$
x \approx\left(h_{0}-h_{1}\right) /\left(R_{0}+h_{0}-h_{1}\right)
$$

where:

$h_{0}$ - specific enthalpy of saturated thermal water at point 0 (Fig. 2),

$h_{1}$ - specific enthalpy of saturated water at flash temperature $t_{1}$. 
Taking into account that $x$ and $h_{1}=f\left(t_{1}\right)$ :

$$
x\left(t_{1}\right)=\frac{h_{0}-h_{1}\left(t_{1}\right)}{R_{0}+h_{0}-h_{1}\left(t_{1}\right)}
$$

Thus, an approximation of parameter $x\left(t_{1}\right)$ is expressed by flash temperature $t_{1}$.

Relationship $\left(h_{2}-h_{3}\right)$ depending on parameter $t_{1}$ is more complicated. It is presented in the fragment of Diagram $(t-h)$ (Fig. 3). Figure 3a shows the processing of the "transfer" working fluid by a hypothetical turbine alongside the line of constant entropy, which is connected to the fall of its temperature $\Delta t$ to condensation value $t_{2}$.

If the lines of constant entropy on Diagram $(t-h)$ in the two-phase area were straight parallel lines, the determination of the relationship between $\left(h_{2}-h_{3}\right)$ and $t_{1}$ at established $t_{2}$ would be simple; namely, according to Figure 3a:

$$
\Delta h_{1} / \Delta t=\left(h_{2}-h_{3}\right) / \Delta t=a=\text { const }
$$

and:

$$
\left(h_{2}-h_{3}\right)=a\left(t_{1}-t_{2}\right)
$$

where $a$-isentropic expansion of heat capacity (the value determined from the lines of constant entropy) $[\mathrm{kJ} /(\mathrm{kg} \cdot \mathrm{K})]$.

However, the lines of constant entropy in Diagram $(t-h)$ (Fig. 3a) do not fulfill the condition of linearity or parallelism, because $a=f\left(t_{1}\right)$ (in reality, alongside the line of constant entropy, the value of parameter $a$ also depends on $t_{2}$ ):

$$
\left(h_{2}-h_{3}\right) \approx a\left(t_{1}\right)\left(t_{1}-t_{2}\right)
$$

According to the data from the diagram in Figure 3a, relationship $a=f\left(t_{1}\right)$ was established and presented in Figure $3 b$. The values of parameter a depend almost linearly on flash temperature $t_{1}$ in the range of temperatures analyzed by the following function:

$$
a\left(t_{1}\right)=7.62-0.0133 t_{1}
$$

From the graph in Figure $3 a$, we can see that, the smaller $t_{1}$ is, the higher $h_{3}$ and smaller $h_{2}-h_{3}$ are - but from Formula (5) - then, the higher $x$ is. Thus, the maximal value of specific power in Expression (2) can only occur at a strictly defined parameter of $t_{1}$.

Putting (5), (8), and (9) to (2), we obtain:

$$
w\left(t_{1}\right)=\eta \frac{h_{0}-h_{1}\left(t_{1}\right)}{R_{0}+h_{0}-h_{1}\left(t_{1}\right)}\left(t_{1}-t_{2}\right)\left(7,62-0,0133 t_{1}\right)
$$


a)

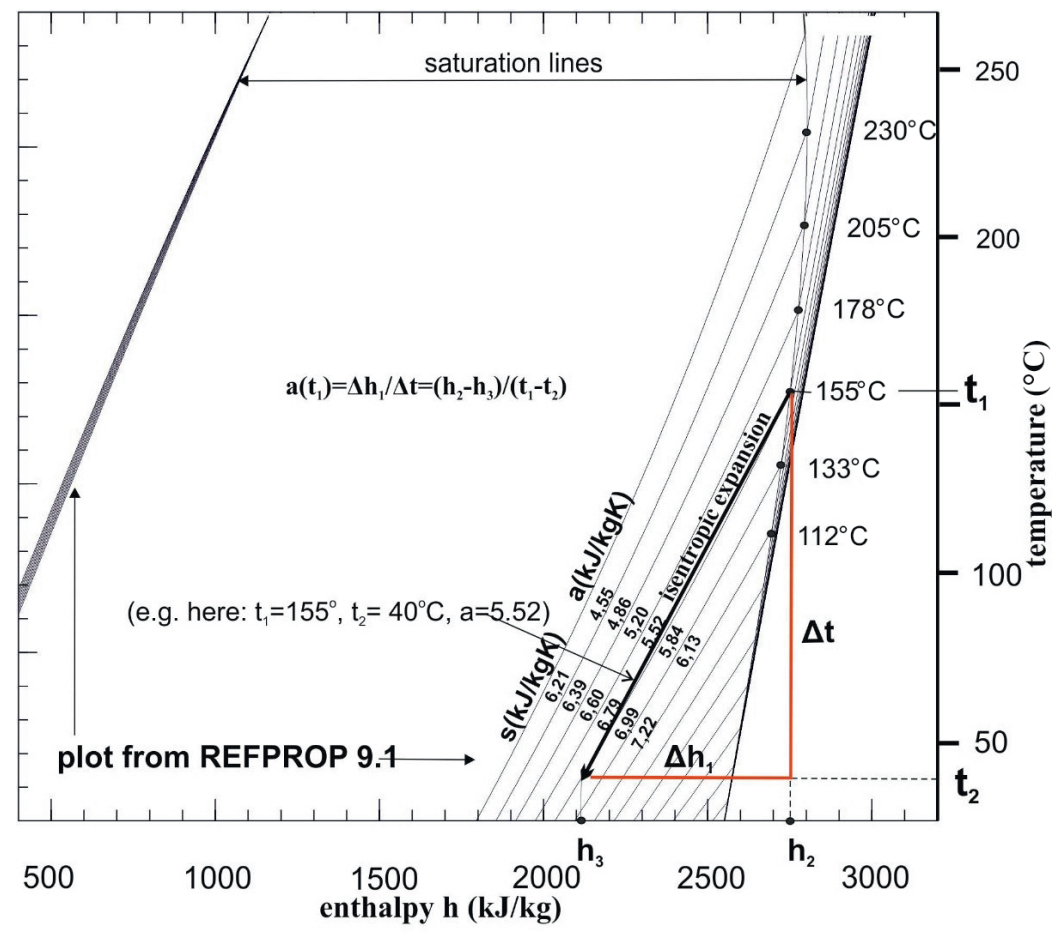

b)

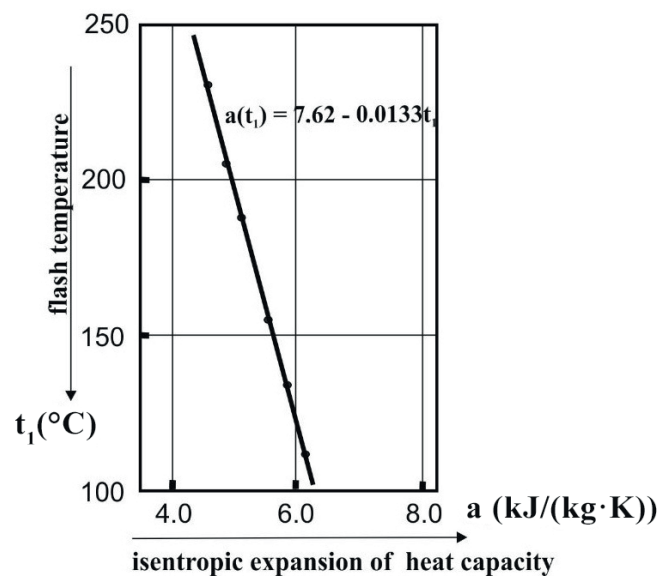

Fig. 3. Values of parameter $(a)$ shown on $(t-h)$ diagram along constant entropy lines of two-phase area (a). Linear extrapolation of a $\left(t_{1}\right)$ function (b)

Expression (10) presents an alternative, semi-analytical formula for the estimation of the specific power of a single flash geothermal plant as a function of flash temperature $t_{1}$, where the established parameters are $\eta, t_{0}$, and $t_{2}$. 
Examples of the calculations of specific power and $t_{1}$ opt for the assumed parameters of the thermal fluid $\left(t_{0^{\prime}} p_{0}\right)$ and assumed condensation temperature $t_{2^{\prime}}$ are shown in Figure 4.

a)

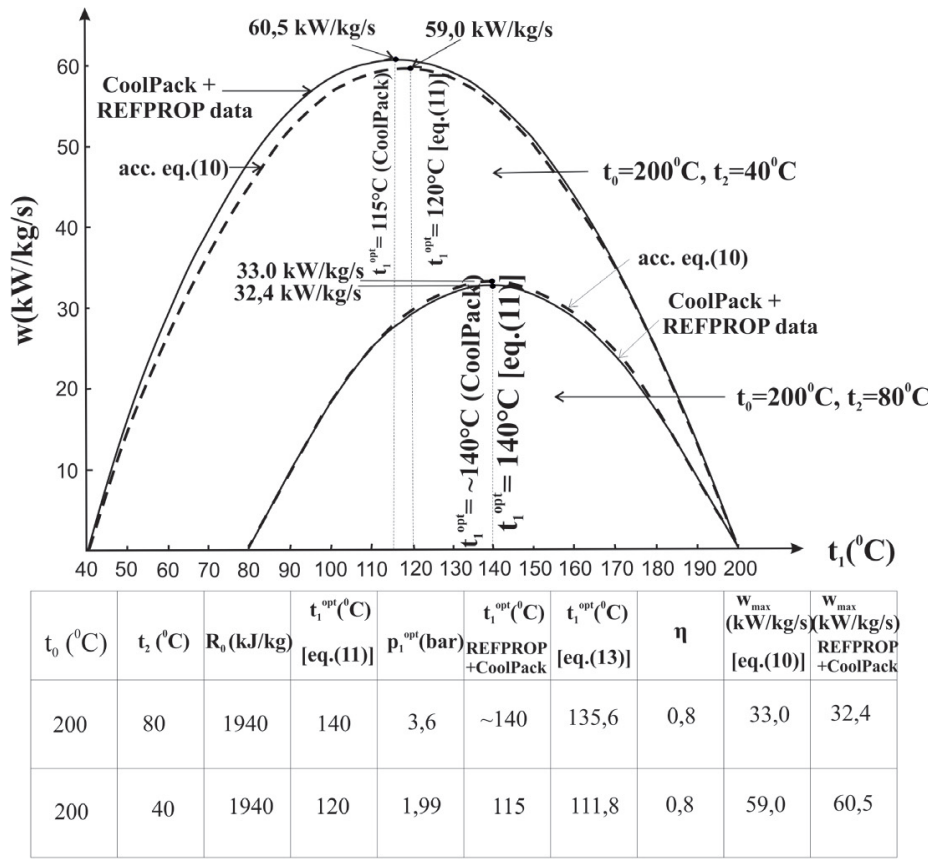

b)

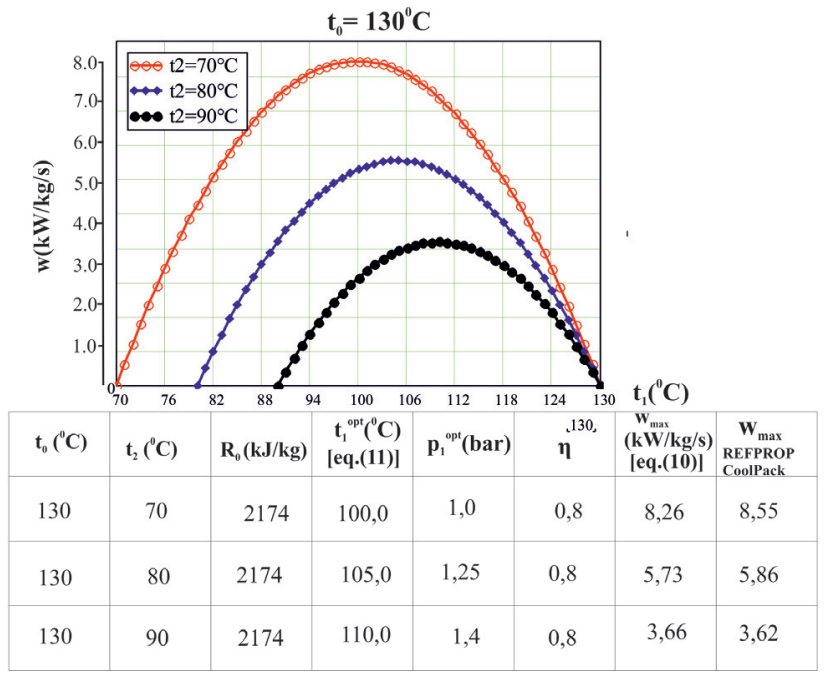

Fig. 4. Plots of specific power for single flash geothermal cycles $(w)$ as a function of flash temperature $t_{1}:$ a) for identical temperatures of thermal fluids $t_{0}$ and different condensation temperatures $t_{2} ;$ b) for identical temperatures of thermal fluids $t_{0}$ and different condensation temperatures $t_{2}$ 
Flash temperature $\mathrm{t}_{1}$ can theoretically decrease to value $t_{2}$ where, according to Formula (10), the power becomes zero.

Function $w\left(t_{1}\right)$ is almost a symmetrical "parabola"; thus, maximum power occurs for the value of $t_{1}$ close to the arithmetic average of $t_{0}$ and $t_{2}$ :

$$
t_{1}^{\mathrm{opt}}=\frac{t_{0}+t_{2}}{2}
$$

The known and simple formula of the maximization of the power output of a flash plant is the one that correlates $t_{1}^{\text {opt }}$ according to the square root of the product of $t_{0}$ and $t_{2}$ (using the Kelvin scale):

$$
T_{1}^{\mathrm{opt}}=\sqrt{T_{0} T_{2}}
$$

or:

$$
t_{1}^{\mathrm{opt}}=\sqrt{\left(t_{0}+273\right)\left(t_{2}+273\right)}-273
$$

Examples of the calculations of specific power and $t_{1}^{\text {opt }}$ for the assumed parameters of the thermal fluid $\left(t_{0^{\prime}} p_{0}\right)$ and assumed condensation temperature $t_{2}$ are shown in Figure 4. The results were compared to the values obtained from the REFPROP and CoolPack databases.

Flash temperature $t_{1}$ can theoretically decrease to value $t_{2}$ where, according to Formula (10), the power becomes zero. The results were compared to the values obtained on the basis of the REFPROP and CoolPack databases and also from the square root formula.

The values of $t_{1}^{\text {opt }}$ and the maximum specific power taken from the REFPROP and CoolPack databases (regarded as accurate) indicate a small deviation from those estimated using Formulas (10) and (11). The estimation error mainly results from the estimation error of parameter $x$ (assumption of $\delta h \approx 0$ in [3]).

Despite the fact that the estimation gives some errors, it allows for a quick and simple assessment of the maximal power of a flash geothermal plant for defined parameters $t_{0}$ and $t_{2}$ through the substitution of value $t_{1}$ opt from (11) or (13) into Expression (10).

\section{Implications for Geothermal Conditions of Poland}

As mentioned above, Polish geothermal resources look much more modest in energy terms when compared to well-known global geothermal resources. Only in the central area of Poland are there realistic local conditions for the production of electricity from geothermal fluids (e.g., the Konin region, [1]); even so, the temperatures of thermal waters occurring in these places do not exceed $130-140^{\circ} \mathrm{C}$. Thus, the possibility of the application of single flash systems is only hypothetical. The values 
of specific power $(w)$ presented in Figure $4 \mathrm{~b}$ significantly depend on the accepted value of temperature $t_{2}$; however, even for the optimal conditions assumed in Poland, they do not exceed a value of $9 \mathrm{~kW} /(\mathrm{kg} / \mathrm{s})$. As shown in Figure $4 \mathrm{~b}$, the highest specific power for a given $t_{0}$ is theoretically obtained from the maximal cooling of liquids exiting the turbine. However, the efficiency of the turbine depends on the relationships between $p_{1}$ and $p_{2}\left(=t_{1}\right.$ and $\left.t_{2}\right)$; additionally, the mass flow rate depends on the value of flash temperature $t$. In Poland, the pressure at the wellhead is also a problem. Although there is the potential possibility of producing the required pressure by installing sufficient deep pumps in the boreholes in the subartesian conditions that often occur in central Poland, the energy consumed by the pumps might drastically lower the value of net power. The total power produced by the well in a flash system may be calculated from the specific power $(w)$ and mass flow rate $(\dot{m})$ :

$$
W=\dot{m} w
$$

For the geothermal conditions in the Lower Triassic reservoirs in central Poland [9], maximal values $\dot{m}$ are about $30 \mathrm{~kg} / \mathrm{s}\left(\sim 100 \mathrm{~m}^{3} / \mathrm{h}\right)$; according to Formulae (10) and (11), the maximal value of specific power $(w)$ that could be obtained is $8 \mathrm{~kW} /(\mathrm{kg} / \mathrm{s})$ for the established conditions of the saturated water: $t_{0}=130^{\circ} \mathrm{C}$, $p_{0}=2.7 \mathrm{bar}$, and $t_{2}=70^{\circ} \mathrm{C}$ (Fig. $4 \mathrm{~b}$ ). Thus, the maximal power of a hypothetical flash system is $\sim 0.8 \mathrm{MW}$. However, even if all of the established conditions were to be fulfilled, the real net power could be about 25\% lower [9] and might not exceed 0.6 MW.

\section{Conclusions}

Based on the analytical estimations carried out, it can be stated that the single flash cycle process is not relevant for Poland. The estimations presented indicate that, even optimistically assuming a mass flow rate of about $100 \mathrm{~m}^{3} / \mathrm{h}$, the proper pressure and thermal conditions $\left(p_{0} \sim 3\right.$ bar gauge, $\left.t_{0}=130^{\circ} \mathrm{C}\right)$, and the significant cooling of fluids exiting the turbine $\left(t_{2} \sim 70^{\circ} \mathrm{C}\right)$, the value of net power would probably be below $0.6 \mathrm{MW}$ (Fig. 4b). Taking into account the investment costs (depth of resources at about $4-5 \mathrm{~km}$ ), the implementation of single flash systems would also not be justified due to economic reasons. On the other hand, the hydrogeothermal conditions of central Poland presented indicate real possibilities for using resources in binary systems $[6,13]$.

The examples of world geothermal plants indicate that a combination of the technology of flash and binary systems can significantly increase the power obtained and (in this manner) improve the efficiency of power plants. However, the temperatures of Polish resources are too low to make such a combination of processes viable (single flash systems need a reservoir temperature in the region of $170-200^{\circ} \mathrm{C}$ to be superior to binary). 
The above conclusions are the result of applying simple analytical formulae for the single flash cycle and providing an alternative method for estimating the maximal specific power. The analysis carried out formulated the relationship between specific power in the single-flash cycle and the value for flash temperature $t_{1}$ representing the decrease of temperature in the geothermal fluid $t_{0}$ during the flash process. The formula defines at which value of flash temperature $t_{1}$ the maximal value of specific power at the established temperatures of geothermal fluid and the established condensing temperature of fluid exiting the turbine is obtained. This is a well-known problem; however, from a scientific point of view, it would be interesting to present the analytical solution and compare the results with those obtained from thermodynamic diagrams and the square root formula. The estimated errors of the procedure applied are within a range of $2-5 \%$ of the values defined on the basis REFPROP and CoolPack data.

In the estimation, the values of some parameters are assumed, whereas these assumptions are not really appropriate for the actual processes occurring during the generation of electricity in a power plant. For instance, the calculations are based on ideal thermodynamic processes, and some values (such as isentropic turbine efficiency) were accepted in an arbitrary manner, while parameter $(x)$ is a crude estimate.

\section{References}

[1] Barbacki A.: Classification of geothermal resources in Poland by exergy analysis Comparative study. Renewable and Sustainable Energy Reviews, vol. 16, 2012, pp. 123-128.

[2] Barbacki A., Uliasz-Misiak B.: Geothermal energy of the Mesozoic Basin in The Carpathian Foredeep, Kraków Region, Poland. Applied Energy, vol. 74, 2003, pp. 65-73.

[3] Bujakowski W., Barbacki A.: Potential for geothermal development in SouthernPoland. Geothermics, vol. 3, 2004, pp. 383-395.

[4] Bujakowski W., Barbacki A., Czerwińska B., Pająk L., Pussak M., Stefaniuk M., Trześniowski Z.: Integrated seismic and magnetotelluric exploration of the Skierniewice, Poland, geothermal test site. Geothermics, vol. 39, 2010, pp. 7893.

[5] Bujakowski W., Pająk L., Tomaszewska B., 2008. Renewable energy resources in The Silesian Voivodship (Southern Poland) and their potential utilization. Mineral Resources Management, Poland, Cracow, vol. 24, pp. 409-426.

[6] Bujakowski W., Tomaszewska B. (red. nauk.): Atlas of the possible use of geothermal waters for combiner production of electricity and heat using binary systems in Poland (Atlas wykorzystania wód termalnych do skojarzonej produkcji energii elektrycznej i cieplnej w układach binarnych w Polsce). Polska Akademia Nauk. Instytut Gospodarki Surowcami Mineralnymi i Energia, Kraków 2014. 
[7] Ciężkowski, W., Farbisz J., Grzegorczyk K.: Projekt głębokiego wiercenia w krystaliniku sudeckim dla potrzeb elektrowni wykorzystujacej ciepło ziemi metoda HDR. Technika Poszukiwań Geologicznych. Geotermia, Zrównoważony Rozwój, nr 1-2, 2011, pp. 81-91.

[8] DiPippo R.: Exergy analysis of combined electricity and direct-heat geothermal flashsteam plants. Geothermal Resources Council Transaction, vol. 11, 1987, pp. 411-416.

[9] Gong Y., Luo C., Ma W., Wu Z.: Thermodynamic Analysis of Geothermal Power Generation Combined Flash System with Binary Cycle. [in:] Proceedings World Geothermal Congress - Bali, Paper 2607, 2010 [CD].

[10] Górecki W. [red.] et al.: Atlas zasobów geotermalnych formacji mezozoicznej na Niżu Polskim [Atlas of geothermal energy resources in the Polish Lowlands. 1. Mesozoic formations]. AGH, Krakow 2006.

[11] Kanoglu M., Dincer I., Rosen M.A.: Understanding energy and exergy efficiencies for improved energy management in power plants. Energy Policy, vol. 35, 2007, pp. 3967-3978.

[12] Kępińska B.: Geothermal energy country update report from Poland, 2010-2014. [in:] Proceedings World Geothermal Congress 2015 - Melbourne, Australia, 19-25 April 2015, Paper 01039, 2015 [CD].

[13] Pająk L., Bujakowski W.: Geothermal energy in binary systems [Energia geotermalna w systemach binarnych]. Przegląd Geologiczny, nr 11/2, t. 61, 2013, pp. 699-705.

[14] Ryley D.J.: An analytical expression in terms of temperature only for optimizing the flash cycle for geothermal power plants. Geothermics, vol. 7, 1978, pp. 9-15.

[15] Shulman G.: Low temperature flashed steam power generation. [in:] Proceedings of the World Geothermal Congress, 1995: Florence, Italy, 18-31 May 1995, International Geothermal Association 1995, pp. 2059-2061.

[16] Stachel A.: Wykorzystanie energii wnętrza Ziemi. Wyd. Uczelniane Zachodniopomorskiego Uniwersytetu Technologicznego, Szczecin 2013.

[17] Tomaszewska B.: Koncepcja odsalania wód termalnych w kontekście poprawy bilansu wodnego. Część II - Wstępne wyniki badań. Biuletyn Państwowego Instytutu Geologicznego, nr 445, 2011, pp. 693-700.

[18] Tomaszewska B.: The use of ultrafiltration and reverse osmosis in the desalination of low mineralized geothermal waters. Archives of Environmental Protection, vol. 37, issue 3, 2011, pp. 63-77.

[19] Tomaszewska B., Pająk L.: Dynamics of clogging process in injection wells used to pump highly mineralized thermal waters into the sandstone structures lying under the Polish Lowlands. Archives of Environmental Protection, vol. 38, issue 3, 2012, pp. 105-117. 


\section{Ocena możliwości wytwarzania energii elektrycznej przy wykorzystaniu obiegów z separacją pary w polskich warunkach geotermalnych}

Streszczenie: Przedstawiono metodykę oceny dostępnej mocy jednostkowej (odniesionej do strumienia płynu geotermalnego) siłowni geotermalnej wykorzystującej obieg z separacją pary (ang. flash system). Analizy prowadzono, uwzględniając temperaturę kondensacji pary wychodzącej z turbiny przy różnej temperaturze złożowej. Zaproponowano metodykę optymalizacji ciśnienia separacji pary przy założeniu, że ekspansja pary w turbinie zachodzi izentropowo. Uwzględniając te założenia, opracowano analityczną zależność umożliwiającą ocenę optymalnej temperatury (której odpowiada optymalne ciśnienie), dla której powinien być prowadzony proces separacji pary i cieczy. Optymalizację prowadzono z zamiarem osiągnięcia maksymalnej mocy elektrycznej dostępnej dla określonego strumienia płynu geotermalnego.

Prezentowane $\mathrm{w}$ artykule rozważania zostały zainicjowane badaniami dotyczącymi możliwości wykorzystania systemów ciepła gorących suchych skał HDR (ang. Hot Dry Rock) i geotermalnych systemów wspomaganych EGS (ang. Enhanced Geothermal System) do produkcji energii elektrycznej w polskich warunkach geotermalnych. W centralnej Polsce w utworach triasu dolnego przewiduje się możliwość eksploatacji płynów geotermalnych o temperaturze ponad $130^{\circ} \mathrm{C}$. Jednak z uwagi na niewielką osiąganą moc elektryczna, w połączeniu z wysokimi przewidywanymi nakładami inwestycyjnymi (wspominane zasoby energii geotermalnej zalegają na głębokościach większych niż 4000 m), wykorzystanie tych systemów raczej nie będzie opłacalne. Zasoby te mogą zostać jednak efektywnie zagospodarowane do wytwarzania energii elektrycznej w siłowniach binarnych.

Słowa

kluczowe: energia geotermalna, siłownie geotermalne, obieg z separacją pary, moc właściwa, Polska 